\title{
Coexistence effect of rotifer, Brachionus rotundiformis and copepod, Oithona similis in culture media on growth performance and eggs production
}

\author{
SUMINTO", DIANA CHILMAWATI \\ Department of Aquaculture, Faculty of Fisheries and Marine Science, Universitas Diponegoro. Jl. Prof. Soedarto, SH, Tembalang, Semarang 50275, \\ Central Java, Indonesia. Tel.:+62-24-7474698, Fax.:+62-24-7474698, `email: suminto57@ gmail.com
}

Manuscript received: 23 May 2019. Revision accepted: 30 July 2019.

\begin{abstract}
Suminto, Chilmawati D. 2019. Coexistence effect of rotifer, Brachionus rotundiformis and copepod, Oithona similis in culture media on growth performance and eggs production. Biodiversitas 20: 2396-2402. The effect of Brachionus rotundiformis, and Oithonasimilis coexistence in culture media on the growth performance and egg production were examined and it aims to know the best coexistence percentage which provides the highest growth performance and egg production of $O$. similis and $B$. rotundiformis. Experiment method was carried out in this research by using a completely randomized design (CRD) with 5 treatments and 4 replications. The treatments were percentage through mix culture ratio of O.similis. and B. rotundiformis whereas those treatments were with ratio of $100 \%$ and $0 \%$ (A); $90 \%$ and $10 \%$ (B); $80 \%$ and $20 \%$ (C); $70 \%$ and $30 \%$ (D); and $60 \%$ and $40 \%$ (E), respectively. The results showed that, $B$. rotundiformis had a significant effect $(\mathrm{p}<0.05)$ on final density, population growth rate and eggs production of Oithona sp.; coexistence of $60 \%$ Oithona sp. and $40 \%$ B. rotundiformis provides the best final density for Oithona sp. (27.40 \pm 0.34 ind. $/ \mathrm{ml})$ and $B$. rotundiformis $(30.23 \pm 0.21 \mathrm{ind} . / \mathrm{ml})$; the highest population growth rate of Oithona sp. $(0.29 \pm 0.02$ ind./day) and $B$. rotundiformis $(0.36 \pm 0.03$ ind./day); and the highest egg production of Oithona sp. (18.83 \pm 0.76 eggs/ind) and B. rotundiformis (3.30 \pm 0.24 eggs/ind.). However, the mix culture of O.similis. and B. Rotundiformis may be applied in co-existent semi-mass or mass culture.
\end{abstract}

Keywords: Coexistence, Brachionus rotundiformis, Oithona similis, growth performance

\section{INTRODUCTION}

Copepoda is one of the potential natural feeds which can be given to the larvae of shrimp and marine fish to increase their growth and survivability (Molejon and Alvarez-lajonchere 2003; Broach 2017). Aliah et al. (2010) stated that there are abundant copepods natural feeds found in nearly all Indonesian waters, including Oithona sp. Moreover, marine fish larvae in their nature usually consume nauplii copepods as their main natural feed (Ma et al. 2013). Referring to Drillet et al. (2006), the success factors of copepod utilization as natural feed is the higher quality of nutrition than other zooplankton. According to Nordgreen et al. (2013), the nutritional quality of rotifer can not supply nutritional requirements of marine fish larvae. Chilmawati and Suminto (2016) stated that Oithona sp. can be used as feed auctions between rotifer and Artemia, or as a substitute for Artemia in the strategy of feeding whiteleg shrimp larvae (Litopenaeus vannamei). Suminto and Chilmawati (2018), reported that there was an increase in growth and egg production of Oithona sp., which is cultured semi-intensively using live food of microalgae cells enriched with fermented organic feed. However, it has not been used as live food in the hatchery of marine fish and shrimp until now.

Contamination with other zooplankton such as rotifer, Brachionus sp. and protozoa, Euplotes sp. frequently occur in a semi-mass culture of Oithona sp. copepod in some
Indonesian marine fish hatcheries (interview with Marine Cultivation Development Center of Lampung (BBPBL) Indonesia 2018). Oithona sp. and Brachionus sp. are mostly used as an interval live feed although there is often any sudden death and population decline in semi-mass or mass culture. This occurs possibly due to the presence of contaminants or coexistence of other zooplankton, which negatively affect Oithona sp. culture. It is because Brachionus sp. can grow and reproduce in high density culture (Srivastava et al, 2006). Based on some studies concerning in semi-mass culture, there is still coexistence ranging from 5-20\% Brachionus rotundiformis found in Oithona sp. culture media.

Brachionus sp. is used as natural food in the hatchery in the form of biocapsule feed for various types of marine larvae (Shields 1999). B. rotundiformis is a type of Rotifera and is the main natural feed for marine fish larvae (Watanabe et al. 1983; Lubzens 1987; Shields 2005). As a natural feed, B. rotundiformis has many advantages due to its nature and characteristics with relatively small size, weak swimming ability, high density cultivated, high reproductive rate, and high nutritional value (Hirayama and Satuito 1991; Snell 1991; Tamaru et al. 1991). Oithona sp. copepod has a higher total content of HUFA (Highly Unsaturated Fatty Acid) from EPA (Eicosapentaenoic Acid, 20: 5n-3) and DHA (Docosahexaenoic Acid, 22: 6n3 ) which is higher than $B$. rotundiformis does, although the EPA content of Oithona sp and B. rotundiformis is almost 
the same, i.e. $9.25 \%$ and $8.9 \%$ respectively, the DHA content of Oithona sp. is much greater than $B$. rotundiformis, i.e. $24.41 \%$, and $12.1 \%$ respectively (Toledo et al 1999; Hamre 2016). The high value of DHA and EPA will eventually result in growth and survival improvement as well as reduce the occurrence of abnormalities in fish larvae (Meeren et al. 2008). Moreover, copepod, Oithona sp. is also known to contain immunostimulant substances, attractants, some important digestive enzymes (amylase, protease, exonuclease and esterase), vitamins (C and E), protein, carbohydrates and lipid (Van der Meeren 2003).

Artemia and rotifer are widely used for shrimp and marine fish larvae. Nevertheless, inherently insufficient for the nutritional needs of essential fatty acids such as 20: 5n3 and 22: 6n-3 (Stottrup et al. 1998). According to Melianawati et al. (2015), the combination of copepod and rotifer diets is able to increase digestive enzyme activity for grouper larvae rather than just copepods or rotifers alone.

Thus, it is necessary to conduct a study to determine the effect of $B$. rotundiformis coexistence in culture media on the growth performance of Oithona sp. The purpose of this study is to examine the effect of $B$. Rotundiformis coexistence on the growth performance of Oithona sp.copepods and to determine the percentage of $B$. rotundiformis coexistence which can provide the highest performance growth and egg production of Oithona sp. and B. rotundiformis.

\section{MATERIALS AND METHODS}

\section{Study area}

This study was conducted at the Coastal Area Development Laboratory (LPWP) of Faculty of Fisheries and Marine Science, Diponegoro University, Jepara, Central Java, Indonesia.

\section{Procedures}

\section{Microalgae culture}

The cell of Chaetoceros calcitrans and Isochrysis galbana were obtained from a pure culture of Live Feed Laboratory, Brackish Water Cultivation Development Center (BBPBAP) in Jepara. Microalgae culture was carried out in a sterile $3 \mathrm{~L}$ volume Erlenmeyer containing 2 $\mathrm{L}$ sterile sea water. The sea water used as the culture was sterilized by adding $30 \mathrm{ppm}$ dose liquid chlorine solution and incubated for 24 hours. Then, $15 \mathrm{ppm}$ sodium thiosulfate was added and after that aeration was done for 24 hours until there was no chlorine odor. Modified Walne media was used for $C$. calcitrans and I. galbana cultures. This Walne media Modification consisted of nutrient solution, i.e. 20 gram $\mathrm{NaH}_{2} \mathrm{PO}_{4} \cdot 2 \mathrm{H}_{2} \mathrm{O}, 100$ gram $\mathrm{NaNO}_{3}$, 45 gram $\mathrm{Na}_{2}$.EDTA, 0.36 gram $\mathrm{MnCl}_{2} .4 \mathrm{H}_{2} \mathrm{O}, 1.3$ gram $\mathrm{FeCl}_{3} .6 \mathrm{H}_{2} \mathrm{O}$, and 33.6 gram $\mathrm{H}_{3} \mathrm{BO}_{3}$, of which were dissolved in $1000 \mathrm{~mL}$ of distilled water as media stock 1; trace metal solution is 2.1 gram $\mathrm{ZnCl}_{2}, 2.0$ gram $\mathrm{CoCl}_{2} .6 \mathrm{H}_{2} \mathrm{O}, 0.9$ gram $\mathrm{CuSO}_{4} .4 \mathrm{H}_{2} \mathrm{O}$, and 2.0 gram $\left(\mathrm{NH}_{4}\right) 8 . \mathrm{Mo}_{7} \mathrm{O}_{24} \cdot 4 \mathrm{H}_{2} \mathrm{O}$, all were dissolved in $100 \mathrm{~mL}$ of distilled water as a media stock 2; Vitamin solution obtained from $10 \mathrm{mg}$ vitamin $\mathrm{B}_{12}, 10 \mathrm{mg}$ Thiamin, $200 \mu \mathrm{g}$
Biotin, all were dissolved in $100 \mathrm{ml}$ of aquadest as a media stock 3 . The culture medium used was $1 \mathrm{~mL}$ from each stock medium 1, 2, and 3 and then sterile seawater was added to $1 \mathrm{~L}$ of media water. Especially for diatom cell cultures, $80 \mathrm{ppm}$ of $C$. calcitrans is added to natrium silicate solution since its growth requires silicates in its culture media (Pal et al. 2013).

Microalgae cell cultures were prepared at $28 \%$ salinity, $26-28^{\circ} \mathrm{C}$ temperature, $7.5-8.0 \mathrm{pH}, 24$ hours irradiation with 1800-2000 lux light intensity and adequate aeration (Suminto and Hirayama 1997; Chilmawati and Suminto 2016). The initial spread of algae cell culture in Erlenmeyer Flask was 10,000 cells $/ \mathrm{mL}$. Algae cells harvesting as Oithona sp. and Brachionus rotundiformis's feed was carried out at the exponential phase since it contains high nutrients (Chilmawati and Suminto 2010; Creswell 2010). Before algae cells were used as feed, microalgae cells (cells $/ \mathrm{mL})$ in the culture, they were calculated with a haemocytometer (Improved Neubauer with $0.0025 \mathrm{~mm}^{3}$ volume) under a microscope (Olympus BX41) with 40x magnification.

Oithona sp. and Brachionus rotundiformis culture

The stock of Oithona sp. seeds was obtained from Marine Cultivation Development Center of Lampung (BBPBL), while $B$. rotundiformis seed stock was obtained from Brackishwater Cultivation Development Center of Jepara (BBPBAP). Some of the Oithona sp. specimens have been analyzed with biomolecular properties to determine the species, and their names are included in the species Oithona similis (Chilmawati et al. 2019). It has been found that more than $99 \%$ of the genetics are similar to the Oithona similis species. Furthermore, naming the Oithona species in this study will use the species name Oithona similis.

The culture used a $50 \mathrm{ml}$ vial glass bottle filled with 20 $\mathrm{ml}$ of sterile sea water. Then, the bottle is covered with one hole on the upper side. $O$. similis and B. rotundiformis biota which are used as the initial spreading was in adult stadia. Based on the size of adult $O$. similis $466 \mu \mathrm{m}$ (NERC 2016) and adult B. rotundiformis $180-230 \mu \mathrm{m}$ (Anitha and George 2006), and the ratio of the initial density used was 1 ind./mL of $O$. similis and 2 ind. $/ \mathrm{mL}$ of B. rotundiformis. The indoor culture was carried out at $28^{\circ} \mathrm{C}$ and $28 \%$ salinity without aeration.

The method of feeding used ad libitum, i.e. microalgae cells were fed with the same total biomass calculated based on the dry weight ratio of each microalgae cell (Lee et al. 2006). The dry weight of algae cells for $C$. calcitrans is $11.3 \mathrm{pg} / \mathrm{cell}$ (Lavens and Sorgeloos 1996), and $25 \mathrm{pg} / \mathrm{cell}$ for I. galbana algae cells (Lee et al. 2006). The dry weight is used as the basis for calculating the number of cells used for the feeding management of both $O$. similis and B. Rotundiformis biota in each treatment. The formula to calculate the number of microalgae cells in each treatment with the basis of the same total biomass is based on the dry weight of each microalgae, $0.01 \mathrm{mg}$ for 1 individual of $O$. similis per day. The formula model for calculating the number of microalgae (Lee et al. 2006) is the Number of microalgae (cells) $=\mathrm{A} / \mathrm{B}$, where $\mathrm{A}$ is the weight of feed $(\mathrm{mg})$ and $\mathrm{B}$ is the dry weight of microalgae $(\mathrm{mg})$. 
The calculation results of the number of microalgae needed for $O$. similis feed is $8.85 \times 10^{5}$ cell/copepod/day for C. calcitrans and $4.00 \times 10^{5} \mathrm{cell} / \mathrm{copepod} /$ day for I. galbana.

\section{Experimental design}

This study used an experimental method carried out in the laboratory. The research design was a completely randomized design (CRD) with 5 treatments and 4 replications. Moreover, these treatments were mixed cultures: (i). A. $0 \%$ B. rotundiformisand $100 \%$ O. similis; (ii). B. $10 \%$ B. rotundiformisand $90 \%$ O. similis; (iii). C. $20 \%$ B. rotundiformisand $80 \%$ O. similis; (iv) D. $30 \%$ B. rotundiformisand $70 \%$ O. similis.; (v). E. $40 \% \quad B$. rotundiformisand $60 \% O$. similis. The density of $O$. similis. and $B$. Rotundiformis in every treatment was calculated every 4 days for 20 days by calculating the total individuals and population-specific growth rates $(\mathrm{r})$.

\section{Data analysis}

Data collection included the growth performance of $O$. similis which was observed through the results of the total individuals of $O$. similis (nauplii, copepodite and adult stadia), the density of females laying eggs and rate of population growth. On the other hand, the total density of $B$. rotundiformis consisted of density in the adult stage and the number of females laying eggs. The observation was conducted using a microscope (Olympus CKY41) with 40x magnification, magnifying glass, Petri disk, and dropper pipette under adequate lighting. Population growth rate (r) was calculated using the initial and final total density data for each treatment. The population growth rate (r) was calculated by the formula used by Cheng et al. (2011) as follows: $r=(\ln \mathrm{Nt}-\mathrm{ln} \mathrm{N} 0) / \mathrm{t}$. Where $\mathrm{t}$ is the last day of observation, N0 and Nt are the initial and final density of $O$. similis (ind./day). Egg production calculation used the formula proposed by Zamora-Terol et al. (2014), i.e. Egg Production $=(\Sigma \mathrm{s} \times \mathrm{e}) /(\Sigma \mathrm{n})$. Where $\mathrm{s}$ is the egg bag, e is the average number of eggs per bag (egg) and $n$ is the number of female laying eggs. The data obtained were then analyzed by variance test (ANOVA) with a 95\% significance level and the median value test was Least Significant Different (LSD) using SPSS 16 (Ghozali 2006).

\section{RESULT AND DISCUSSION}

\section{Results}

The final density of $O$. similis and $B$. Rotundiformiscoexistence in the culture on treatment day 20 th can be seen in Figure 1. The final density of $O$. similis reflects the number of $O$. similis individuals in nauplii, copepodite, adult copepods and females laying eggs stadia per milliliter of culture media. In contrast, $B$. rotundiformis is described by the total number of young, mature and female laying eggs stadia. The final density of each $O$. similis and B. rotundiformis in treatment $\mathrm{E}$ respectively is $27.40 \pm 0.34 \mathrm{ind} . / \mathrm{ml}$ and $30.23 \pm 0.21$ ind. $/ \mathrm{mL}$ which shows the highest final density $(\mathrm{p}<0.05)$ compared to the other treatments. Furthermore, treatment $\mathrm{D}$ shows the second highest with $25.83 \pm 0.39$ ind./mL and $28.08 \pm 0.38$ ind./mL; treatment $\mathrm{C}$ is $22.05 \pm 0.42$ ind. $/ \mathrm{mL}$ and $16.13 \pm 0.30$ ind. $/ \mathrm{mL}$; treatment $\mathrm{B}$ is $12.73 \pm 0.22$ ind. $/ \mathrm{mL}$ and $0.39 \pm 0.05$ ind./mL; and treatment $\mathrm{A}$ results in $11.95 \pm 0.42$ ind./mL and $0.00 \pm 0.00$ ind. $/ \mathrm{mL}$.

All treatments show a significantly different effect $(\mathrm{p}<0.05)$ on the final density of $O$. similis and $B$. rotundiformis. Average density of $O$. similis at each stadium, Naupli stadium (Figure 2), copepodite (Figure 3), adult copepods (Figure 4) and females laying eggs (Figure 5 ), shows fluctuative growth. The average density of $O$. similis at a nauplii stadium in all treatments shows an increase on the 12th day and continues to increase except in treatments $\mathrm{A}$ and D. Treatment $\mathrm{E}$ shows a higher number of naupli and continues to increase until the end of the observation. The highest average density of $O$. similis at copepodite stage is shown in treatment $\mathrm{E}$ on day 16th. On the day 20th, the average density of copepodite decreases except in treatment D which seems to keep increasing. The highest density of adult stadium Oithona sp.can be seen in treatment A on day $16^{\text {th }}$ and it decreases on day $20^{\text {th }}$. The average density of adult stages in other treatments shows similar results. The average number of females laying eggs continues to increase in all treatments except in treatment E. In addition, the increase in the number of females laying eggs continues to increase until the $12^{\text {th }}$ day. The number of females laying eggs in Treatment A still increases slightly until the $16^{\text {th }}$ day.

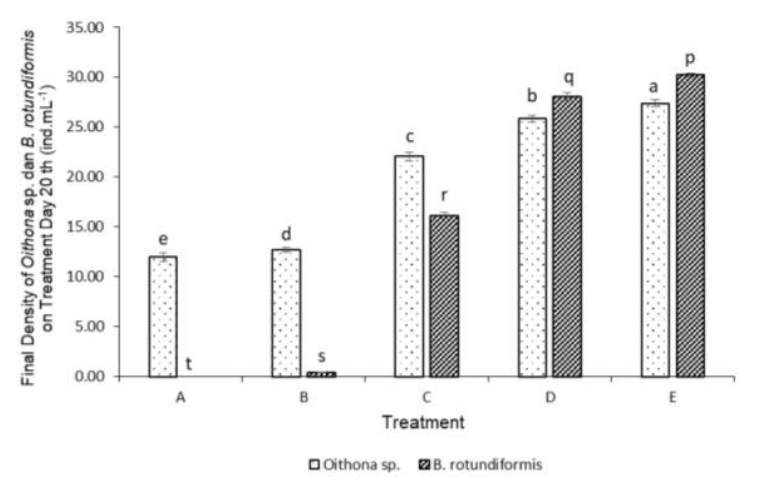

Figure 1. Final density of $O$. similis and Brachionus rotundiformis coexistence in culture on treatment day $20^{\text {th }}$

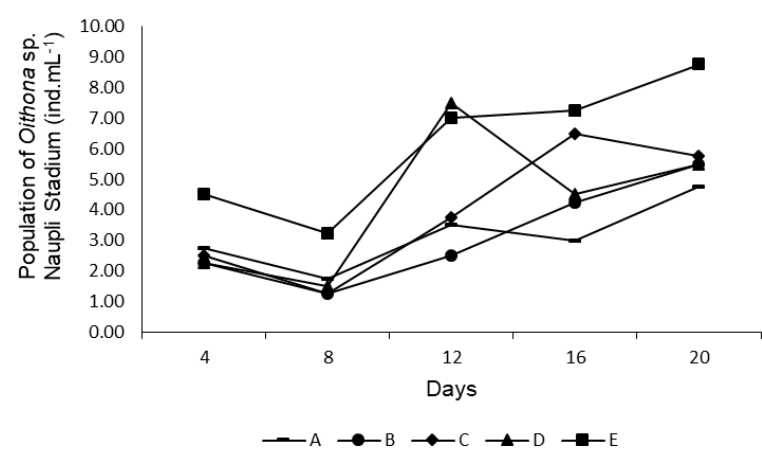

Figure 2. Average density of $O$. similis in Nauplii stadium for 20 days 


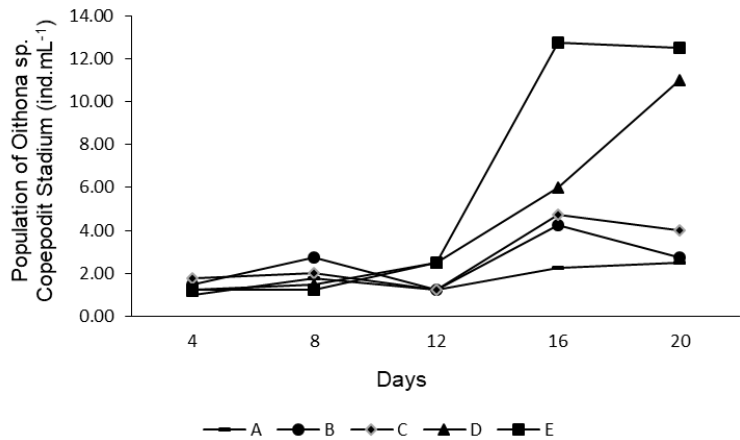

Figure 3. Average density of $O$. similis at Copepodit stadium for 20 days

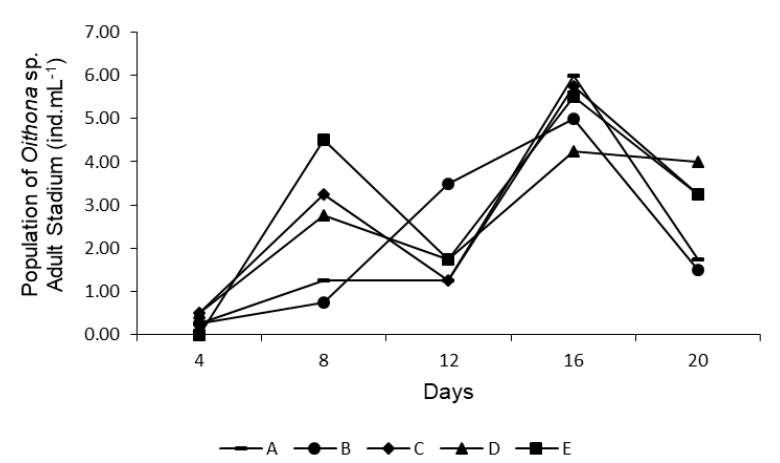

Figure 4. Average density of $O$. similis at adults stadium for 20 days

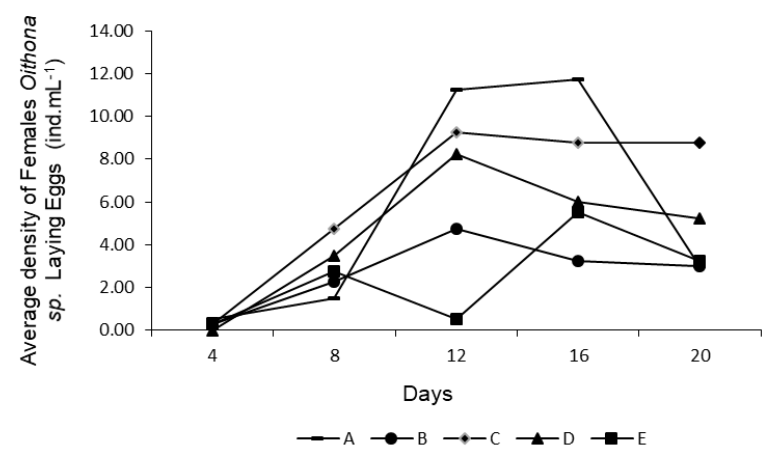

Figure 5. Average density of females $O$. similis laying eggs for 20 days

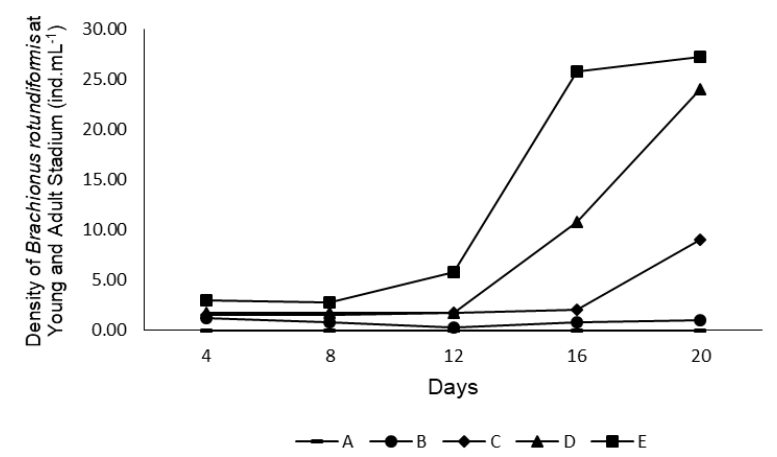

Figure 6. Density of Brachionus rotundiformisat young and adult stadium
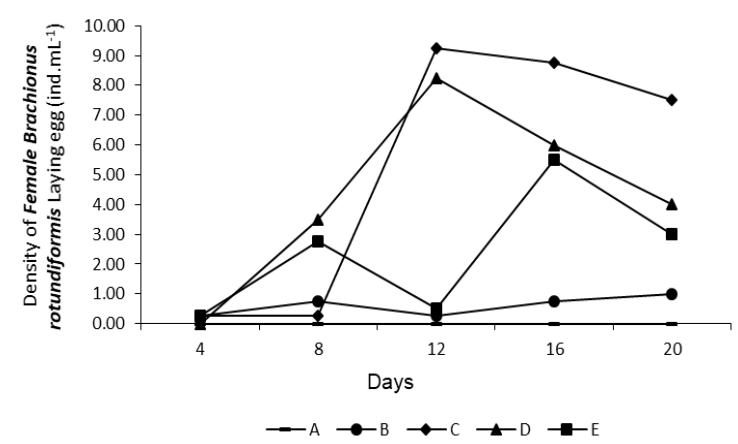

Figure 7. Density of Female Brachionus rotundiformis Laying egg (ind. $\mathrm{mL}^{-1}$ )

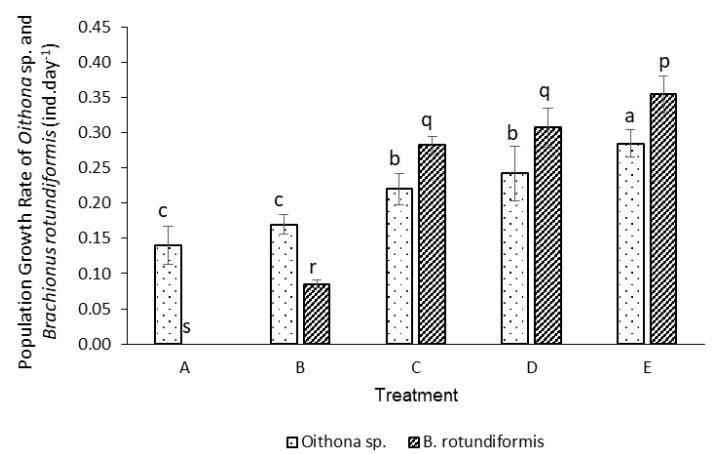

Figure 8. Population growth rate of $O$. similis and Brachionus rotundiformis

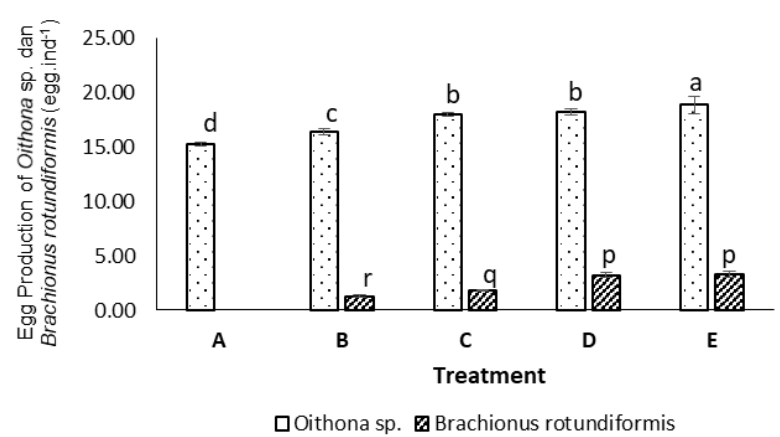

Figure 9. Egg production of $O$. similis dan Brachionus rotundiformis

The average value of copepod egg production of $O$. similis and $B$. rotundiformis is described in Figure 9. The coexistence of $B$. rotundiformis in $O$. similis copepod culture significantly affects the egg production of both $B$. rotundiformis and Oithona sp. Treatment E shows the highest average value of $O$. similis egg production and it is followed by treatment D, C, B and A. Besides, the Smallest Significant Difference test (LSD) shows that there is a significant difference $(\mathrm{p}<0.05)$ among the treatments, except for treatment $\mathrm{C}$ and $\mathrm{D}$.

The average density of adult and female $B$. rotundiformis laying eggs can be seen in Figure 6 and Figure 7 . The average number of adult $B$. rotundiformis 
individuals begins to increase on the 12th day until the end of the observation, the 20th day. The average density of adult $B$. rotundiformis significantly increases In treatment $\mathrm{D}$ and $\mathrm{E}$ on the 16th day. This is different from treatment $\mathrm{A}, \mathrm{B}$, and $\mathrm{C}$. The density of $\mathrm{B}$. rotundiformis in each treatment shows varied results. Treatment $C$ shows the highest average number of females $B$. rotundiformis laying eggs than other treatments.

The population growth rate of $O$. similis and $B$. Rotundiformis in each treatment is presented in Figure 8. The highest average population growth rate for $O$. similis and $B$. rotundiformis is found in treatment $\mathrm{E}, 0.29 \pm 0.02$ ind./day and $0.36 \pm 0.03$ ind./day respectively. Then, it is followed by treatment D with $0.24 \pm 0.04$ ind./day for $O$. similis and $0.31 \pm 0.03$ ind./day for $B$. rotundiformis. Treatment $C$ results in $0.22 \pm 0.02$ ind./day and $0.28 \pm 0.01$ ind./day, while treatment $\mathrm{B}$ is $0.17 \pm 0.01$ ind./day and $0.09 \pm 0.01$ ind./day respectively. Treatment A shows the lowest average population growth rate for $O$. similis, $0.14 \pm 0.03$ ind./day, and $0.00 \pm 0.00$ ind./day. for $B$. rotundiformis.

Based on the results of the Least Significant Different (LSD) on the population growth rate of $O$. similis, it shows that treatment $E$ is significantly different $(p<0.05)$ with treatment D, C, B, and A. Treatment D is not significantly different from treatment $\mathrm{C}$ but is significantly different from treatment $\mathrm{B}$ and $\mathrm{A}$. Moreover, treatment $\mathrm{C}$ is also significantly different from treatment $\mathrm{B}$ and $\mathrm{A}$, while treatment B is not significantly different from treatment A.

The results of LSD analysis on the population growth rate of $B$. rotundiformis shows that treatment $\mathrm{E}$ is significantly different from treatment D, C, B, and A. Treatment $\mathrm{D}$ is not significantly different from $\mathrm{C}$ but is significantly different from treatment B and A. Similarly to treatment $\mathrm{C}$, treatment $\mathrm{B}$ is also significantly different from treatment $\mathrm{A}$.

\section{Discussion}

Based on the results of this study, it shows that the coexistence of $B$. rotundiformis in copepod culture media of $O$. similis gives a significant influence $(\mathrm{p}<0.05)$ on the final density, rate of population growth and egg production of both $O$. similis and $B$. rotundiformis.

Treatment E consisting of $60 \%$ O. similis and $40 \% \mathrm{~B}$. rotundiformis mixed culture provides the best final density for both $O$. similis $(27.40 \pm 0.34$ ind. $/ \mathrm{mL})$ and $B$. rotundiformis $(30.23 \pm 0.21$ ind../mL). The best population growth rate is also obtained in treatment $\mathrm{E}$, for both $O$. similis $(0.29 \pm 0.02 \mathrm{ind} . / \mathrm{day})$ and $B$. rotundiformis $(0.36 \pm 0.03$ ind./day). The highest egg production value is shown in treatment E, O. similis (18.83 \pm 0.76 eggs/ind) and B. rotundiformis $(3.30 \pm 0.24$ eggs/ind). This is presumably due to the feed available in the culture with such ratio according to the needs of $O$. similis and $B$. rotundiformis and this eventually results in optimal utilization of feed for both growth and egg production. The types of cell or microalgae used as feed in this study are C. calcitrans and I. galbana which are the best mixtures for copepod feed since both are rich in essential fatty acid content that can affect the high survivability and growth (Puello-Cruz et al.
2009) According to Jeyarad and Santhanam (2013), I. galbana is advantageous for being rich in HUFA especially DHA that will provide a good growth effect for nauplii and early copepodite stadia.

Furthermore, the feces of $B$. rotundiformis are presumably able to be used as additional feed for $O$. similis Thus; it can increase the growth and the population growth rate of $O$. similis. This strengthens Jung's result (2012) stating that marine copepods generally use bacteria and rotifer feces as natural feed at the initial nauplii stadium. Consequently, the presence of $B$. rotundiformis is beneficial for $O$. similis naupli.

Jung (2012) stated that copepods use their feeding mechanism by filtering the feed and the rotifer is simultaneously slowly filtered along with the food. However, the rotifer is immediately spat out again. The spewed rotifer seems to be injured or has physical damage. This physical damage caused by copepods will lead to a decrease in the growth of rotifer density. The other factor causing rotifers not to grow is due to its smaller size characteristics than copepods, namely 180-220 $\mu \mathrm{m}$ (Rusdi 1997).

The increase of $B$. rotundiformis percentage in $O$. similis culture media results in increasing production results indicated by the final density of both $O$. similis and B. rotundiformis rotifer (Figure 1.). This result shows that there is a mutually beneficial relationship (mutualism symbiosis) between $O$. similis copepod and $B$. rotundiformis rotifer. This study consequently agrees with the results of previous studies stating that many contaminant microorganisms affect the population growth of rotifer through interactions, such as exploitative competition for food, commensalism, amensalism and physical disruption competition (Hagiwara et al. 1995; Jung et al. 1997).

The population growth rate of $O$. similis also tends to increase along with the increasing percentage of $B$. rotundiformis coexistence (Figure 8). Treatment E shows the best the population growth rate of $O$. similis copepod and $B$. rotundiformis rotifer. This population growth rate is probably influenced by the feed given. This includes the type of algae, the amount of feed, algae size and the content of algae such as PUFA and phosphate (Cheng et al. 2011). The process of maturity and production of $O$. similis naupli can occur when the microalgae content meets the nutritional needs to grow and develop.

In addition, the quantity and quality of the feed also significantly affect egg production (Drillet et al. 2011; Noyon and Froneman, 2013; Rajthilak et al. 2014). The nutrient components produced from phytoplankton, $C$. calcitrans and I. galbana, including n-3 HUFA especially EPA and DHA, are such important factors for egg fecundity and development (Lee et al. 2006).

Noyon and Froneman (2013) also suggested that the other factors influencing egg production besides feed are physical parameters (temperature, salinity) and seston composition, i.e., chlorophyll a, protein, carbohydrates, and lipid concentrations such as fatty acid composition. Moreover, it is stated that temperature plays an important role in metabolic rate as well as in the rate of egg 
production. The temperature will affect the female size. Therefore, it will also affect egg production (Hansen et al. 2009). Uchima (1979) has proven that under optimum conditions, it will produce 16-54 eggs, while on previous research it only produced 12-24 eggs.

Both $O$. similis and $B$. rotundiformis are zooplankton to feed marine/shrimp fish larvae. In marine shrimp/fish larvae feeding strategy, the early development of larvae requires rotifers including $B$. rotundiformis, besides copepod, O. similis at naupli or copepodite stadia. After the size of the mouth opening increases, the role of $O$. similis at adult or female laying eggs stadia are highly needed more than rotifers because Copepoda has the content of with a lot of advantages including high essential fatty acids EPA, DHA and ARA which are required by fish larvae in the early stages of their development (Watanabe et al. 1983; Witt et al. 1984). Copepoda was chosen due to its relatively short life cycle, around 14 days from egg to adult and it has a relatively small size around $60-220 \mu \mathrm{m}$ which is fit with the mouth opening of fish larvae. In addition, copepods also have such zigzag short and interrupting sliding movement that attracts more attention than rotifer and artemia (Lavens and Sorgelos 1996). This shows that coexistence of $B$. rotundiformis in $O$. similis culture gives a good influence on the growth performance and egg production of copepod as natural feed for shrimp and marine fish larvae. It needs to conduct further research on the application of mixed cultures of $O$. similis and $B$. rotundiformis in mass scale under optimal environmental conditions.

Coexistence of rotifer, $B$. rotundiformis, and $O$. similis in culture media significantly affects the final density, population growth rate, and egg production of $O$. similis copepod. Coexistence of $40 \%$ B. rotundiformis and $60 \%$ O. similis results in the best final density, population growth rate and egg production of $O$. similis and B. rotundiformis rotifer. Furthermore, the results should be disseminated to fish farming community so that they can apply this in the hatchery. Therefore, the needs of natural feed from zooplankton can support the production of shrimp and marine fish larvae.

\section{ACKNOWLEDGEMENTS}

We would like to acknowledge Triya and Maya who have prepared and helped in tabulating the data. We would also like to thank Mrs. Vanny for helping to correct the spelling and grammar.

\section{REFERENCES}

Aliah R, Kusmiyati S, Dedy Y. 2010. Pemanfaatan copepoda Oithona sp sebagai pakan hidup larva ikan kerapu. Pusat Teknologi Produksi Pertanian-BPPT, Jakarta. [Indonesian]

Anitha PS, George RM. 2006. The taxonomy of Brachionus plicatilis species complex (Rotifera: Monogononta) from the Southern Kerala (India) with a note on their reproductive preferences. J Mar Biol Ass India 48 (1): 6-13.

Broach JS, Cassiano EJ, Watson CA. 2017. Baseline culture parameters for the cyclopoid copepod Oithona colcarva: a potensial new live feed for marine fish larviculture. Aquaculture Research 48: 44614469.

Chilmawati D, Suminto. 2010. Effect of the use of bread yeast, vitamin $b_{12}$, and vitamin $c$ as feed enrichment ingredients for the increase in Brachionus plicatilis population. Jurnal Saintek Perikanan 5 (2): 4248. [Indonesian]

Chilmawati D, Suminto. 2016. The effect of different diet of phytoplankton cells on growth performance of copepod, Oithona sp. in semi-mass culture. Aquatic Procedia 7: 39-45

Chilmawati D, Hutabarat J, Anggoro S, Suminto S. 2019. biomolecular identification and optimization of growth performance and egg production in Oithona sp. under different salinity culture conditions. AACL Bioflux 12 (2): 575-585.

Cheng S, Samba K, Kumar R, Chung-Su K, Jiang-Shiou H. 2011. Effect of salinity, food level, and the presence of microcrustcean zooplankters on the population dynamics of rotifer Brancionus rotundiformis. Hydrobiologia 666: 289-299.

Creswell L. 2010 Phytoplankton Culture for Aquaculture Feed. Southern Regional Aquaculture Center. SRAC Publication No. 5004.

Drillet G, Jørgensen NOG, Sørensen TF, Ramløv H, Hansen BW. 2006. Biochemical and technical observations supporting the use of copepods as relevant live feed organisms in marine larviculture. Aquac. Res. 37, 756-772.

Drillet G, Frouel S, Sichlau MH, Jepsen PM, Hojgaard JK, Joarder AK, Hansen BW. 2011. Status and recommendation on marine copepod cultivation for use as live feed. Aquaculture 315: 155-166

Ghozali I. 2006. Aplikasi Analisis Multivariate dengan Program SPSS. Ed. IV, Badan Penerbit Universitas Diponegoro, Semarang.

HagiwaraA, Jung M, Sato T, Hirayama K. 1995. Interspecific relations between marine rotifer Brachionus rotundiformis and zooplankton species contaminating in the rotifer mass culture tank. Fisheries Science 61 (4): 623-627.

Hamre K. 2016. Nutrient profiles of rotifers (Branchionus sp.) and rotifer diets from four different marine fish hatcheries. Aquaculture 450: 136-142.

Hansen BW, Drillet G, Kozmer A, Madsen KV, Pedersen MF, Sorensen TE. 2010. Temperature effects on copepods egg hatching: does acclimatization matter?. J Plankton Res 32 (3): 305-315.

Hirayama K Satuito CG. 1991. The nutritional improvement of baker's yeast for the growth of the rotifer, Branchionus plicatilis. In: Fulks, W and K.L. Main (eds) 1991. Rotifer and Microalgae Culture Systems. Proceedings of a U.S.-Asia Workshop. The Oceanic Institute Makapuu. Honolulu, Hawaii.

Jeyarad N, Santhanam P. 2013. Influence of algal diet on population density, egg production and hatching succesion of the calanoid copepod, Paracalanus parvus (Claus, 1863). J Algal Biomass Utln (1): 1-8. 43.

Jung MM, Hagiwara A, Hirayama K. 1997. Interspecific interactions in the marine rotifer microcosm. Hidrobiologia 358: 121-126.

Jung M. 2012. Survival strategies of the rotifer Brachionus rotundiformis for coexisting with the copepod Apocyclops borneoensis in laboratory culture. Fish Aquat Sci (2012): 57-62.

Lavens P, Sorgeloos P. 1996. Introduction. In: P. Lavens and P. Sorgeloos (Eds.). Manual on the Production and Use of Live Food for Aquaculture. FAO Fisheris Technical Paper. No. 361, Food and Agriculture Organization of the United Nations, Rome, Italy.

Lee KW, Park HG, Lee SM, Kang HK. 2006. Effect of diets on the growth of the brackish water cyclopoid Copoped Paracyclopina nana Smirnov. Aquaculture 256: 346-353.

Lubzens E. 1987. Raising rotifers for use in aquaculture. Hydrobiologia. 147: 254-255.

Ma Z, Guo H, Zhang HN, Bai Z. 2013. State of art for larval rearing of grouper. Intl J Aquacult 3 (13): 63-72.

Melianawati R, Pratiwi R, Puniawati N, Pujiastuti P. 2015. The effect of various kind of live feeds to digestive enzymes activity of coral trout Plectropomus leopardus (Lacepede, 1802) larvae. Intl J Fisher Aquat Stud. 3 (2): 83-88.

Molejon OGH, Lajonchere A. 2003. Culture experiments with Oithona oculata Farran, 1913 (Copepoda: Cyclopoida), and it's advantages as food for marine fish larvae. Aquaculture 219: 471-483.

NERC (Natural Environment Research Council). 2016. Zooplankton Identification Manual for Northern European Seas (ZIMNES), http: //192.171.193.133/index.php.

Nordgreen A, Penglase S, Hamre K. 2013. Increasing the levels of the essential trace elements $\mathrm{Se}, \mathrm{Zn}, \mathrm{Cu}$ and $\mathrm{Mn}$ in rotifers (Brachionus plicatilis) used as live feed. Aquaculture 380-383: 120-129 
Noyon M, Froneman PW. 2013. Variability in the egg production rates of the calanoid copepod, Pseudodiaptomus hessei in a South African estuary in relation to environmental factors. Estuarine, Coastal and Shelf Science 30: 1-11.

Pal SW, Singh NK, Azam K. 2013 Evaluation of relationship between light intensity (lux) and growth of Chaetoceros muelleri. Oceanography 1 (3): 1-4. DOI: 10.4172/2332-2632.1000111

Puello-Cruz AC, Mezo-Villalobos S, González-Rodríguez B, Voltolina D. 2009. Culture of the calanoid copepod Pseudodiaptomus euryhalinus (Johnson 1939) withdifferent microalgal diets. Aquaculture 290: 317 319.

Rusdi I. 1997. Growth of the rotifer (Brachionus rotundiformis) Type-S at different temperatures in the. J. Penelitian Perikanan Indonesia 3 (4) 62-66 [Indonesian]

Snell T. 1991. Improving the Design of Mass Culture System for Rotifer, Branchionus plicatilis. In: Fulks W, Main KL (eds). Rotifer and Microalgae Culture Systems. Proceedings of a U.S.-Asia Workshop. The Oceanic Institute Makapuu.Honolulu, Hawaii.

ShieldsRJ, Bell JG, Luizi FS, Gara B, Bromage RN, Sargent JR. 1999. Natural copepods are superior toenriched Artemia nauplii as feed for halibut larvae (Hippoglossus hippoglossus) in terms of survival, pigmentation and retinal morphology: relation to dietaryessential fatty acids. J Nutr 129: 1186-94.

Shields RJ, Kotani T, Molnar A, Marion K, KobashigawaJ, Tamg L. 2005. Intensive cultivation of a subtropical paracalanid, copepod, Parvocalanus sp., as prey for small marine fish larvae, in Lee C-S O'Bryen P J and Marcus N.H. (eds), Copepods in Aquaculture. Blackwell Publishing, Oxford.

Srivastava A, Hamre K, Stoss J, Chakrabarti R, Tonheim S K. 2006. Protein content and amino acid composition of the live feed rotifer (Brachionus plicatilis): With emphasis on the water soluble fraction. Aquaculture 254: 534-543

Stottrup J, Shields R, Gillespie M, Gara, MB, Sargent JR, Bell JG Henderson RJ, Tocher DR, Sutherland R, Naess T, Mangor Jensen A,
Naas K, Vander Meeran T, Harboe T, Sanchez FS, Soegelos P, Dhert P, Fitzgerald R. 1998. The production and use of coipepod in larval rearing of halibut, turbot and cod. Bull Aquacult Assoc Canada 4: 4146.

Suminto, Chilmawati D, Harwanto D. 2018. Effect of different doses of fermented organic feed on the growth performance of Oithona sp. in semi-mass culture condition. OMNI-AKUATIKA Fisher Mar Sci Nat Protect Commun Welf 14 (3): 53-59.

Tamaru CS, Sheng-LeeC, Ako H. 1991. Production of rotifers for striped mullet larvae. In: Fulks W, Main KL (eds). Rotifer and Microalgae Culture Systems. Proceedings of a U.S.-Asia Workshop. The Oceanic Institute Makapuu.Honolulu, Hawaii.

Toledo JD, Golez MS, Doi M,Ohno A. 1999. Use of Copepod nauplii during early feeding stage of grouper Epinephelus coioides. Fisheries Science 65 (3): 390-397.

Uchima M. 1979. Morphological observation of development Stages in Oithona brevicornis (Copepod, Cyclopoid). Bulletin of Plankton Society of Japan, 26 (2): 59-76.

Van der Meeren, T. 2003. Analysis of biochemical componets in copepods for evaluation of feed quality for juvenile production of marine fish.prosjektrapport nr 52003 Havforskningsinstituttet. 39 pages.

Watanabe T, Kitajima C, Fujita S. 1983. Nutritional values of live organisms used in japan for mass propagation of fish: a Review. Aquaculture (34): 115-143.

Witt U, Quantz G., Kuhlmann D, Kattner G. 1984. Survival and growth of turbot larvae Scopthalmus maximus L reare don different food organisms with special regard to long-chain polyunsaturated fatty acids. Aquaculture Engineering (3): 177-190.

Zamora-TerolS, Swalethorp R, Kjellerup S, Saiz E, Nielsen TG. 2014. Population dynamics andproduction of the small copepod Oithonasp. in a subarctic fjord of West Greenland. Polar Biology 37: 953-965. 